\title{
Law and Economics Workshop
}

September 22, 2014

\section{The Rising Son under the Shadow of Company Communities: Do Japanese Family Firms Really Excel?}

\author{
Presenters: Zenichi Shishido* and Noriyuki Yanagawa" \\ (Co-authors: Takuji Saito and Hokuto Dazai ${ }^{* *}$ )
}

\footnotetext{
${ }^{*}$ Professor of Law at Graduate School of International Corporate Strategy, Hitotsubashi University, Japan; Visiting Professor at U.C. Berkeley Law School.

\#Professor, Graduate School of Economics, The University of Tokyo, Japan; Visiting Scholar at U.C. Berkeley Law School.

^Associate Professor, Graduate School of Business Administration, Keio University, Japan.

${ }^{* *}$ Ph.D. candidate, Hitotsubashi University, Japan.
} 


\begin{abstract}
Japanese corporate governance has long attracted attention from scholars due to its stark differences from the Anglo-Saxon model. Indeed, scholars have pointed to the unique aspects of Japanese governance to explain Japan's economic miracle, only to reverse their view, citing it as a major factor behind the lost decades of the ' 90 s and '00s. A recent study by Mehrotra, Morck, Shim, and Wiwattanakantang (2013) brings Japanese economic governance back into the spotlight. In their analysis of family-run firms, the authors find that although inherited control is linked to poor firm performance in other developed economies, heir-run firms actually perform well in Japan. In search of a convincing explanation for this finding, we studied the same sample of firms over the same period and reached varying results. Our paper relies on the concept of a "company community" to explain why Japanese family firms appear to outperform non-family firms. The company community, consisting of management and shareholders, is the core of the Japanese non-family listed firm. Japanese family firms, on the other hand, modify the characteristics of the company community to avoid critical defects in monitoring, incentives, and external labor markets. Rather than concluding that Japanese family firms performed well, the more plausible explanation may be that Japanese listed firms on the whole performed badly.
\end{abstract}




\section{Introduction}

Japanese corporate governance has long attracted attention from scholars due to its stark differences from the Anglo-Saxon model. Indeed, scholars once pointed to the unique aspects of Japanese governance to explain Japan's economic miracle, only to reverse their view, citing it as a major factor behind the lost decades of the '90s and '00s. Recently, Professors Mehrotra, Morck, Shim, and Wiwattanakantang [hereinafter MMSW] brought Japanese corporate governance back into the spotlight with their study of family firms (MMSW, 2013).

MMSW discovered what appears to be another Japanese puzzle: whereas inherited control is linked to poor firm performance in other developed economies, heir-run firms perform well in Japan. According to MMSW's data, heir-run firms outperformed not only non-family firms but also family firms run by salaryman CEOs, as measured by both ROA and Tobin's $q$ (all listed firms from 1962 to 2000).

MMSW investigated Japan's unique practices of arranged marriage and adult adoption, and concluded that these practices are keys to solving the puzzle of Japanese family firms. They argue that one in ten successions to non-blood heirs render Japanese family firms more professionally managed by working as hostile takeover-like threats to blood sons and by creating a non-blood-heir job incentive for professional managers. In fact, their data show that non-blood heirs outperform blood heirs.

Although MMSW's adopted-son-in-law hypothesis wonderfully explains their data, it does not sound plausible to most Japanese. We believed that there must be another reason for the relatively good performance of Japanese family firms. We performed a statistical analysis of the same sample firms over the same period and tried to find a different perspective on Japanese family firms.

Our data show some of the same results reached by MMSW, but some different results as well. It is true that family firms (excluding founder firms) outperform non-family firms in ROA for the same period (1962-2000) and for the same samples (all listed companies) as MMSW's data. Tobin's $q$ is, however, worse in family firms than non-family firms. Also, there is no statistically significant difference in performance of family firms run by either non-blood heirs, blood heirs, or salarymen, both in ROA and Tobin's $q$.

We started from two assumptions that (i) the corporate governance of Japanese family firms, including the role of the adopted son-in-law system, must have undergone change over time, and (ii) there must be variation between the larger, high performance listed firms, and the smaller, mediocre listed firms.

We divided MMSW's data period (1962-2000) into the following three eras: $1^{\text {st }}$ Era is prior to the Japanese bubble economy (1962-1985) [High growth economy; Peak of main bank and crossshareholding system]; $2^{\text {nd }}$ Era is during the bubble up until the Japanese financial crisis (1986-1992) [Bubble and burst of bubble; Waste of free cash-flow]; and $3^{\text {rd }}$ Era is after the financial crisis (1993-2000) [Lost decade; Decreasing cross-shareholding and main bank power]. We obtained the following results.

First, non-blood outperformed non-family firms and salarymen in ROA in the $1^{\text {st }}$ Era only. There is no statistically significant difference between blood and non-blood for all the three eras. Second, blood outperformed non-family firms in ROA for both the $2^{\text {nd }}$ Era and $3^{\text {rd }}$ Era. Third, salarymen outperformed non-family firms in ROA in the $3^{\text {rd }}$ Era. There is no statistically significant difference between blood and 
salarymen for all the three eras. And fourth, non-blood, blood, and salarymen were all valued negatively by the stock market, particularly in the $2^{\text {nd }}$ Era. There is no statistically significant difference in Tobin's $q$ among non-blood, blood, and salarymen for all the three eras.

We also divided the MMSW's sample firms by listed class: $1^{\text {st }}$ class listed firms of the Tokyo, Osaka, and Nagoya Stock Exchanges (hereinafter, $1^{\text {st }}$ Class); and $2^{\text {nd }}$ class listed firms of the Tokyo, Osaka, and Nagoya Stock Exchanges, plus listed firms of local exchanges [Sapporo and Fukuoka] (hereinafter, $2^{\text {nd }}$ Class). We obtained the following results.

First, non-blood outperformed not only non-family firms, but also blood and salarymen in the $2^{\text {nd }}$ Class, but not in the $1^{\text {st }}$ Class. Second, blood outperformed non-family firms both in the $1^{\text {st }}$ Class and $2^{\text {nd }}$ Class.

In summing up our data, the following results are important. First, Japanese family firms are run efficiently, but rather are negatively valued. Second, non-blood showed good performance in mediocre listed firms, particularly in the $1^{\text {st }}$ Era. Third, blood showed good performance in the $2^{\text {nd }}$ Era and $3^{\text {rd }}$ Era in both $1^{\text {st }}$ and $2^{\text {nd }}$ Class firms. Finally, salarymen showed good performance in the $3^{\text {rd }}$ Era.

To explain the results of our data, we would like to propose the company community hypothesis.

The "company community," which consists of management and core employees, is the core of the Japanese non-family listed firm (Shishido, 2000). There are three major characteristics of the company community. First, ownership is dispersed but stabilized by cross-shareholdings. Therefore, shareholders' monitoring is weak and company communities can pursue their own private benefit at the cost of shareholders. As a result, ROA and ROE of Japanese listed firms are generally lower than their U.S. counterparts. Second, company communities are egalitarian. As a result, Japanese management compensation is lower (less difference between CEO compensation and median employee compensation) and less incentivized (smaller percentage of equity linked compensation in CEO compensation) than US counterparts. And third, the company community concept is based on long term employment and illiquid external labor markets (Gilson \& Roe, 1999).

We argue that Japanese family firms modify these three characteristics of the company community, which generally work against the interests of shareholders, in a pro-shareholder direction.

First, in family firms, shareholders' monitoring has worked because of the block-holding by founders' families who have incentives and information to monitor management. We consider it the major reason for their higher ROA than non-family firms.

Second, in Japanese listed companies, only blood CEOs have a substantial equity incentive. Non-blood CEOs do not necessarily have an equity incentive because they have no right of inheritance except as they are adopted.

And third, the adopted son-in-law system may have worked as a substitute to the external labor market for management, but did not necessarily work as a threat to blood sons and as an incentive to salarymen. Anecdotally, non-blood CEOs are rarely chosen from the company community, but mostly from outside of the company community, and, in most cases, non-blood CEOs are not replacements of blood sons, but "bridges" from founders to blood sons. In mediocre listed firms where there was no external labor market for management at all, particularly in the $1^{\text {st }}$ Era, the internal labor market was also insufficient. Non- 
blood CEOs may have been the only possible alternatives. On the other hand, in large listed firms, internal labor markets were developed and, recently, even external labor markets for management have emerged (See e.g., Shiseido, Benesse, Suntory, and Nippon Densan).

Ultimately, it may be more accurate to say that Japanese listed firms in general performed badly from a shareholders' interest point of view, rather than saying that Japanese family firms performed well. Among all Japanese listed firms, family firms more closely resemble Anglo-Saxon firms. This is the reason why Japanese family firms look as though they perform better relative to non-family firms, which are generally dominated by company communities.

\section{Previous studies}

Recently, the costs and benefits of family firms have been discussed widely, based on the classic owner-manager agency problem (Berle and Means, 1932; Jensen and Meckling, 1976) and the agency problem between large and small shareholders. In many family firms, the founding families hold a large equity stake and also occupy senior management positions. The potential benefit of managers having large ownership stakes is that it provides them with strong financial incentives to improve firm performance. In addition, Leland and Pyle (1977) suggest that high levels of managers' ownership help signal a firm's quality when information asymmetries exist between managers and outside shareholders. ${ }^{1}$

The potential cost of large concentrated shareholders is that they take actions that pursue private benefits at the expense of other shareholders and firm performance (Shleifer and Vishny, 1997). Several papers show that founding families seek private benefits from the management of their family firms. Perez-Gonzalez (2006) and Bennedsen et al. (2007) show that nepotism within a family firm hurts firm performance. Perez-Gozalez (2006) examines 500 US firms and finds that when the current family CEO announces his/her resignation, the share price rises sharply if the incoming CEO is an external manager and falls if it is another family manager. Bennedsen et al. (2007) find that in Denmark, family succession lowers firm performance. Bertland et al. (2008) show that in Thailand, a wider involvement of family members in family firms lowers firm performance.

Whether family firms outperform nonfamily firms or not is an empirical matter, because there are costs and benefits associated with founding family involvement. Several studies examine a relationship between family firms and firm performance, and have mixed results. Anderson and Reeb (2003) investigate the relationship between family firms and firm performance in the US. They find that family firms perform better than nonfamily firms and conclude that family firms have an effective organizational structure. Moreover, McConnaughy et al. (1998) find that in the US, family firms are also more efficient and valuable than nonfamily firms. In contrast, Claessens et al. (2002) show that in Southeast Asian countries, family firms underperform relative to nonfamily firms. Cronqvist and Nilsson (2003) find that in Sweden, the value of family firms is largely discounted. Barth et al. (2004) show that in Norway, family firms owned and managed by the founding family are less productive than nonfamily firms.

\footnotetext{
${ }^{1}$ Bertrand and Schoar (2006) discuss family firms from a broad perspective.
} 
More recent studies focus on the importance of the generation of the family management and family structure in family firms, and still have mixed results. Villalonga and Amit (2006) examine the relationship between family firms and Tobin's $q$ in the US. They conclude that founder-CEO firms outperform nonfamily firms however, when descendants serve as CEOs, firm value is destroyed. Morck et al. (2000) find that in Canada, family firms controlled by an heir exhibit poor financial performance. Bloom and Van Reenen (2007) find that in France, Germany, the UK, and the US, poor management practices are more prevalent in family firms managed by a founder's descendant. However, Sraer and Thesmar (2007), who, in France, find a premium for family firms, even if they are managed by descendants of founders.

Several papers analyze the reason that family firms outperform in some countries, but not in others. Burkart et al. (2003) model the control succession decisions of family firms and argue that founding families choose to preserve control within the family if the level of protection given to minority shareholders is weak. Consistent with this prediction, Claessens et al. (2000) and Faccio and Lang (2002) show that a family firm is the dominant form of ownership structure in Asia and continental Europe, where the protection of minority shareholders is, in general, weak. Maury (2006) compares the performance of family-controlled firms among Western European countries. He finds that family ownership is associated with higher firm valuations in countries with higher minority shareholder protection.

For family firms in Japan, there are two contrastive studies. Saito (2008) estimates the valuation of family firms using the sample period from 1990 to 1998. He finds that the performance of family firms both owned and managed by the founder's descendants is inferior to that of nonfamily firms. In contrast, Morck et al. (2013) show that family firms managed by the descendants outperform nonfamily firms using the sample period from 1962 to 2000 .

\section{Data descriptions}

\section{Sample and family firm data}

For our examination, we use data from The Corporate Financial Databank (compiled by the Development Bank of Japan), which includes all the companies listed in both the $1^{\text {st }}$ and $2^{\text {nd }}$ Classes of the stock exchanges of Tokyo, Osaka, Nagoya, Sapporo, and Fukuoka. From this list of firms, we exclude financial firms and public utility firms. Our sample period is 1962-2000.

To identify the founders and founding families of all sample firms, we use Nihon Kaisya-shi Soran (published by Toyo Keizai Shinposya), which provides firm history of all the listed firms in 1995. When we are unable to use Nihon Kaisya-shi Soran to identify the founder and founding family, we use Yuka Syoken Hokokusyo and company Websites. Additional information on family relationships is from Nikkei Telecom 21 and Zaikai Kakeifu Taikan, published by Tokiwa Shoin ${ }^{2}$. Next, we obtain the ownership data for all the sample firm-years from Large shareholder/director database (compiled by Institute of Economic Research, Hitotsubashi University) and The Corporate Financial Databank. In Japan, many founding families have a holding company or foundation. To identify these companies and foundations, we refer to the substantial shareholding report submitted to the Ministry of Finance and Yuka Syoken

\footnotetext{
${ }^{2}$ Zaikai Kakeifu Taikan presents family trees of about 1,030 business leaders in 1977.
} 
Hokokusyo. Finally we collect management data for all the sample firm-years. The information on the companies' senior managers (president and chairman) is sourced from Large shareholder/director database and Yakuin Shikiho (published by Toyo Keizai Shinposya), which provides names and titles of all the directors of public companies in Japan. If founding families, ownership, and management data are still missing, we exclude them from our sample. Our sample ends up with 63,521 firm-years from 1962 to 2000.

\section{Variables}

We classify Japanese family firms as follows, to investigate the relationship between firm performance and family firm characteristics. FOUNDER equals one if founder is a president (shacho) or chairman (daihyo torishimariyaku kaicho), and equals zero otherwise. FAMILY equals one if founder's heir is a senior manager (president or chairman) and/or founding family is a top ten shareholder, and equals zero otherwise. $B L O O D$ equals one if a founder's blood heir is a senior manager, and equals zero otherwise. $N O N-B L O O D$ equals one if a founder's adopted son or son-in-law is a senior manager, and equals zero otherwise. SALARYMAN equals one if a founding family is a top ten shareholder and a senior manager is a non-family member, and equals zero otherwise. If both senior managers are founding family members, we prioritize the president.

Our primary performance measures are ROA and Tobin's $q$. ROA is the ratio of operating income before tax and interests to book value of assets. Tobin's $q$ is market value of shares plus book value of total debt divided by market value of assets. We estimate market value as share price time shares outstanding.

We use firm size, leverage, and age as control variables. ASSET is book value of assets. LEVERAGE is the ratio of liabilities with interest to total assets. $A G E$ is the number of years since incorporation. Year and Industry code (based on the classification of the stock exchange of Tokyo) fixed effects control for sectoral and macro factors. All performance measures and control variables are obtained from The Corporate Financial Databank and Kabuka CD-ROM, published by Toyo Keizai Shinposya. To attenuate the outlier effects, we winsorize these variables at $1 \%$. 


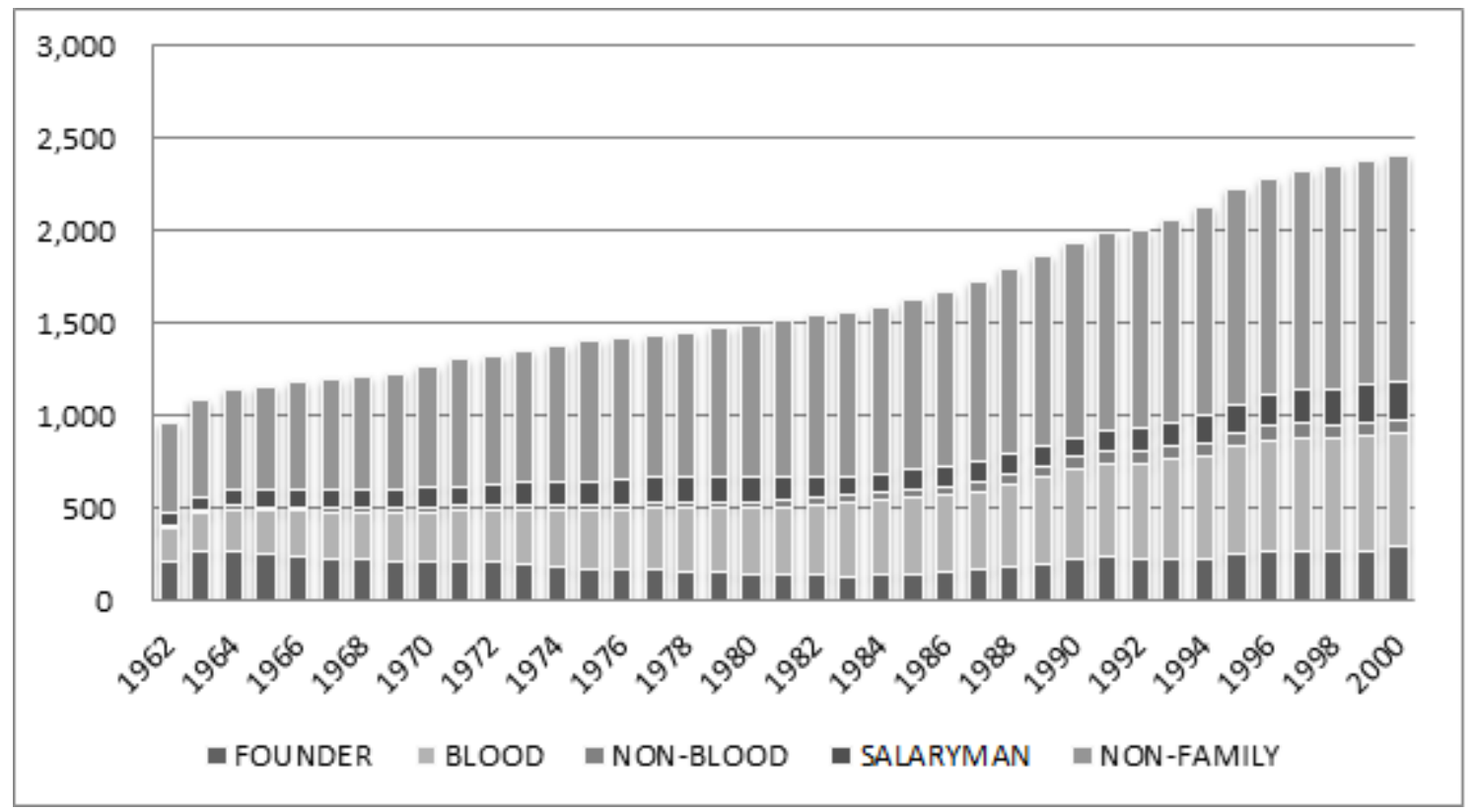

Figure 1 Trend data of family firms

\section{Trend data of family firms}

Figure 1 shows the change in number of family firms from 1962 through 2000. The sample consists of the firms listed on the 1st and 2nd Classes of the stock exchanges of Tokyo, Osaka, Nagoya, Sapporo, and Fukuoka between 1962 and 2000, with financial firms and public utility firms excluded. FOUNDER is a firm where the senior manager (president or chairman) is the founder. FAMILY is defined as those in which the founder's heir is a senior manager and/or the founding family is a top ten shareholder. $B L O O D$ is a firm where the senior manager is the founder's blood heir. $N O N-B L O O D$ is a firm where the senior manager is the founder's adopted son or son-in-law. SALARYMAN is a firm where the founding family is the top ten shareholder, but the senior manager is non-family member.

\section{Summary statistics}

Table 1 Summary statistics

\begin{tabular}{lcccccc}
\hline & \multicolumn{2}{c}{ Firm-year } & & & & Standard \\
& observations & Mean & Median & Min & Max & deviation \\
& 63,509 & 7.444 & 6.964 & -9.116 & 30.099 & 4.820 \\
\hline ROA(\%) & 63,495 & 1.374 & 1.201 & 0.494 & 7.754 & 0.586 \\
Tobin's q & 63,521 & 123.000 & 29.700 & 0.388 & $3,300.000$ & 332.000 \\
ASSET(billion yen) & 63,521 & 30.477 & 29.511 & 0.000 & 81.518 & 18.663 \\
LEVERAGE(\%) & 63,521 & 43.648 & 42.000 & 7.000 & 105.000 & 17.611 \\
AGE(years) & & & & &
\end{tabular}

Table 1 shows the summary statistics of our samples. The sample consists of the firms listed on the 1 st and 2nd Classes of the stock exchanges of Tokyo, Osaka, Nagoya, Sapporo, and Fukuoka from 1962 to 2000 , with financial firms and public utility firms excluded. $R O A$ is the ratio of operating income before tax and interests to book value of assets. Tobin's $q$ is market value of shares plus book value of total debt 
divided by market value of assets. ASSET is book value of assets. LEVERAGE is the ratio of liabilities with interest to total assets. $A G E$ is the number of years since incorporation. We winsorize these variables at $1 \%$ to attenuate the outlier effects.

From this Table 1, we can understand that the variance of asset size is relatively high. It means that heterogeneity of Japanese family firms is relatively high.

Table 2 Summary statistics and firm characteristics

\begin{tabular}{lcccccc}
\hline & FOUNDER & FAMILY & \multicolumn{3}{c}{} & NON- \\
\cline { 4 - 6 } & & & BLOOD & NON-BLOOD & SALARYMAN & \\
\hline ROA(\%) & 9.613 & 7.412 & 7.438 & 7.313 & 7.364 & 6.944 \\
Tobin's q & 1.510 & 1.349 & 1.357 & 1.336 & 1.327 & 1.357 \\
ASSET(billion yen) & 50.400 & 95.400 & 86.600 & 166.000 & 100.000 & 159.000 \\
LEVERAGE(\%) & 26.973 & 28.125 & 28.228 & 26.839 & 28.224 & 32.834 \\
AGE(years) & 27.849 & 44.896 & 45.540 & 46.689 & 42.238 & 46.632 \\
Firm-year observations & 8,085 & 21,729 & 15,334 & 1,599 & 4,796 & 33,707 \\
\hline
\end{tabular}

This Table 2 shows the summary statistics for family firms and non-family firms. FOUNDER is a firm where the senior manager (president or chairman) is the founder. FAMILY is defined as those in which the founder's heir is a senior manager and/or the founding family is a top ten shareholder. $B L O O D$ is a firm where the senior manager is the founder's blood heir. $N O N-B L O O D$ is a firm where the senior manager is the founder's adopted son or son-in-law. SALARYMAN is a firm where the founding family is the top ten shareholder, but the senior manager is non-family member. Data and other variables are as defined in Table 1.

\section{Empirical tests}

Table 3 Family firms and ROA

\begin{tabular}{|c|c|c|c|}
\hline \multirow[t]{4}{*}{ Panel A } & \multicolumn{3}{|l|}{ OLS regression } \\
\hline & Dependent variables= & \multicolumn{2}{|c|}{ ROA } \\
\hline & \multirow[t]{2}{*}{ Model= } & \multicolumn{2}{|c|}{ Pooled OLS } \\
\hline & & (1) & $(2)$ \\
\hline \multirow{2}{*}{\multicolumn{2}{|c|}{ FOUNDER }} & $0.014 * * *$ & $0.014 * * *$ \\
\hline & & $(0.001)$ & $(0.001)$ \\
\hline \multirow[t]{2}{*}{ FAMILY } & & $0.003 * * *$ & \\
\hline & & $(0.001)$ & \\
\hline \multirow[t]{2}{*}{ BLOOD } & & & $0.004 * * *$ \\
\hline & & & $(0.001)$ \\
\hline \multirow{2}{*}{\multicolumn{2}{|c|}{ NON-BLOOD }} & & $0.004^{* *}$ \\
\hline & & & $(0.002)$ \\
\hline \multirow{2}{*}{\multicolumn{2}{|c|}{ SALARYMAN }} & & 0.001 \\
\hline & & & $(0.002)$ \\
\hline ASSET(log) & & $0.003 * * *$ & $0.003 * * *$ \\
\hline
\end{tabular}




\begin{tabular}{lcc}
\hline & $(0.000)$ & $(0.000)$ \\
LEVERAGE & $-0.095^{* * *}$ & $-0.095^{* * *}$ \\
& $(0.003)$ & $(0.003)$ \\
AGE(log) & $-0.014^{* * *}$ & $-0.014^{* * *}$ \\
& $(0.001)$ & $(0.001)$ \\
Intercept & $0.142^{* * *}$ & $0.142^{* * *}$ \\
& $(0.007)$ & $(0.007)$ \\
Industry dummy & Yes & Yes \\
Year dummy & Yes & Yes \\
\hline Sample Size & 63,509 & 63,509 \\
Adj. R $^{2}$ & 0.378 & 0.378 \\
\hline Panel B $\quad$ F-test of differences in model coefficients (null hypothesis) & \\
\hline BLOOD = NON-BLOOD & - & 0.13 \\
& & $(0.721)$ \\
BLOOD = SALARYMAN & - & 2.21 \\
& - & $(0.137)$ \\
NON-BLOOD = SALARYMAN & & 1.68 \\
& & $(0.195)$ \\
\hline
\end{tabular}

$* * *, * * *$ indicate statistical significance at $1 \%, 5 \%$, and $10 \%$ (two-tail) test levels, respectively.

Panel A of this Table 3 shows the results of pooled OLS regressions. Data and all variables are the same as those defined in Tables 1 and 2. Robust standard errors (clustered by firm) are in parentheses. Panel B of this table shows the results of F-test which test the null hypothesis that the coefficients of each family firm are the same. Parentheses are $p$-values.

The results of this table are not so different from the results of MMSW. The performance, ROA, of the family firms is significantly better than that of non-family firms, even though we excluded the founder firms from the group of family firms. MMSW pointed out that the high performance of non-blood heirs is the crucial aspect for understanding Japanese family firms and the "adopted son" is the main actor of the non-blood heirs. Even in our regression, the performance of non-blood firms is superior to non-family firms and it may be true that the role of non-blood heirs is important. However, our results are different from those of MMSW in some aspects. First, the performance of blood heir firms is comparable to that of non-blood heir firms. Second, the performance of professional management firms is not significantly better than non-family firms.

These empirical results cast doubt on the story of MMSW. MMSW focused on unique Japanese practices of arranged marriage and adult adoption, and conclude that these practices were keys to solve the puzzle of Japanese family firms. They argue that one in ten successions to non-blood heirs render Japanese family firms more professionally managed by working as hostile takeover-like threats to blood sons and by creating the non-blood-heir job incentive for professional managers. However, their understanding of adopted-sons is slightly different from that commonly understood in Japanese society. Here we examine the concept of adopted-son more carefully and derive the main differences between our story and the MMSW's story.

The main differences between our paper and MMSW are the following points. "Non-blood heirs" in Japanese family firms are (1) not "adopted sons," (2) not a "takeover" of blood heirs, (3) not a prize to incentivize internal competition. Here we discuss these three points more carefully. 
(1) Non-blood heirs are not "adopted sons."

In Japan, a "son-in-law" can be classified into the following three categories: (i) the husband of a blood daughter, (ii) a husband of a blood daughter who changed his last name to the daughter's family name but was not adopted, (iii) a husband of a blood daughter who changed his last name and was adopted by the daughter's father.

Now, it is impossible for third parties to check whether a son-in law is actually adopted or not. Therefore it is impossible to distinguish (ii) and (iii). Another big problem is Japanese usually refer to category (ii) as "muko-youshi," and this word is translated into "adopted son", even though they are not adopted legally. This means that many "adopted sons" may not actually be adopted. Incidentally, one of the authors of this paper, Dazai, changed his last name but was not adopted.

In the Japanese legal system, there is little difference between categories (i) and (ii). "Muko-youshi" (translated to "adopted son") does not have the right of direct inheritance. This point is important for understanding the financial motivation of "adopted son." They do not have a strong financial linkage to the family business as compared to the blood heirs.

(2) The adopted son is a "bridge."

MMSW have stressed that non-blood heirs work just like a takeover threat for blood heirs, and this threat promotes the incentives of blood heirs. MMSW insisted that this is one reason for the high performance of Japanese family firms. However, it is rare to see a case in which an adopted son excluded the blood heirs. There are several cases where an adopted son became CEO at the exclusion of blood heirs, but in these cases, the blood heirs were too young to become CEO. In Japanese firms, seniority is important for sustaining the society. Hence it is difficult to become CEO if a blood heir is too young-even if he has sufficient talent or potential. In such cases, talented adopted sons are effective. In other words, non-blood heirs may not work as the takeover threat predicted by MMSW and non-blood heirs usually behave as a "bridge" to blood sons.

A good example of this "bridge" phenomenon is a case which taken up by MMSW. MMSW describe the history of Kajima to explain the behavior of non-blood heirs. Historically, non-blood heirs of Kajima managed the firm. However, as MMSW discuss, a blood heir did become CEO of following the non-blood heirs. They explained: "after the younger son-in-law ascended from CEO to Chairman did Morinosuke's biological son serve as CEO” (p. 842).

(3) The "adopted-son" is not a "prize."

MMSW have stressed that the possibility of becoming a non-blood heir works as a special prize for internal workers. That possibility gives a strong motivation to the internal workers and promotes their incentives. However, cases of such internal promotion are quite rare. Further, the example of Suzuki Motors, explained in MMSW, is not a true example of internal promotion.

MMSW explain the Suzuki Motors case as follows: "Suzuki Motors relies extensively on adoptees for the top job, currently held by Mr. Osamu Suzuki. Born Osamu Matsuda, he graduated from Chuo University in 1953, and worked at a bank until 1958 when, at age 28, he was adopted by the patriarch, Shunzou Suzuki, married a Suzuki daughter (Shoko), and took the Suzuki name. Osamu joined Suzuki's board in 1963, became President in 1978, and Chair in 2000."

From this explanation, we can understand that Osamu Matsuda was not a worker at Suzuki Motors when he married a Suzuki daughter. He was working at a bank. This means that he was not selected from the internal society of Suzuki Motors. He was actually an outsider of Suzuki Motors and just 
joined the society as an adopted-son. (As we have explained above, Osamu Matsuda changed his last name to Suzuki, but this does not necessarily mean that he became adopted.)

This is a typical case of an adopted son. Recently the share of arranged marriages is decreasing but even in such cases, a son-in-law is selected from outside of a family firm - not from inside the firm itself. In other words, the adopted- son is not selected through an internal competition and thus the position of adopted-son cannot function as a special prize.

Based on these examinations, we find that MMSW's theory cannot explain the mechanism of Japanese family firms. But because the high performance of non-blood heirs is a prominent characteristic of Japanese firms, we must show another plausible theory for explaining it. Here we present a mechanism along the lines of the company community hypothesis. As discussed in the Introduction, the "company community," consisting of management and core employees, is the core of the Japanese non-family listed firm (Shishido, 2000). The company community is characterized by three major traits: (1) dispersed ownership, stabilized by crossholdings; (2) egalitarianism as measured by CEO compensation (including equity linked compensation); and (3) long term employment and illiquid labor markets (Gilson \& Roe, 1999). In a firm dominated by the company community, dispersed ownership will weaken shareholders' monitoring, as company communities can pursue their own private benefit at the cost of shareholders. This helps explain why the ROA and ROE of Japanese listed firms are generally lower than their U.S. counterparts. Further, egalitarianism means that Japanese managers earn less (including equity based compensation) and are thereby less incentivized than their US counterparts.

Our argument is that Japanese firms are able to modify all three characteristics of the company community, which ordinarily work against the interests of shareholders, in a pro-shareholder direction. Another way to put this is that Japanese family firms more closely resemble Anglo-Saxon firms than Japanese non-family firms, which are generally dominated by the company community. It is the company community that explains why the average ROA of Japanese firms is significantly lower than that of the US firms. Ultimately, then, it may be more accurate to say that Japanese listed firms in general performed badly from the shareholders' interest point of view, rather than saying that Japanese family firms performed well.

It is possible to explain the high performance of non-blood heirs more plausibly by using our theory. As we show, non-blood heirs are not the winners of internal competitions but professional managers selected from outsiders. In other countries, especially in the United States, non-family firms are managed by professional managers selected from the outside market. In Japan, however, non-family firms are managed by internally promoted managers, whereas non-blood heirs of family firms are the exception. A typical example is Osamu Matsuda in Suzuki Motors as explained by MMSW. In other words, the adopted son-in-law system may have worked as a substitute to the external labor market for management.

\section{Family firms and ROA (sub-samples of time period)}

The Japanese labor market is changing over time. Labor mobility is gradually increasing. Hence, in order to examine our conjecture, we divided the MMSW's data period (1962-2000) into the following three eras: $1^{\text {st }}$ Era is prior to the Japanese bubble economy (1962-1985) [High growth economy; Peak of 
main bank and cross-shareholding system]; $2^{\text {nd }}$ Era is during the bubble up until the Japanese financial crisis (1986-1992) [Bubble and burst of bubble; Waste of free cash-flow]; and $3^{\text {rd }}$ Era is after the financial crisis (1993-2000) [Lost decade; Decreasing cross-shareholding and main bank power]. Table 4 shows the obtained results.

Table 4 Family firms and ROA (sub-samples of time period)

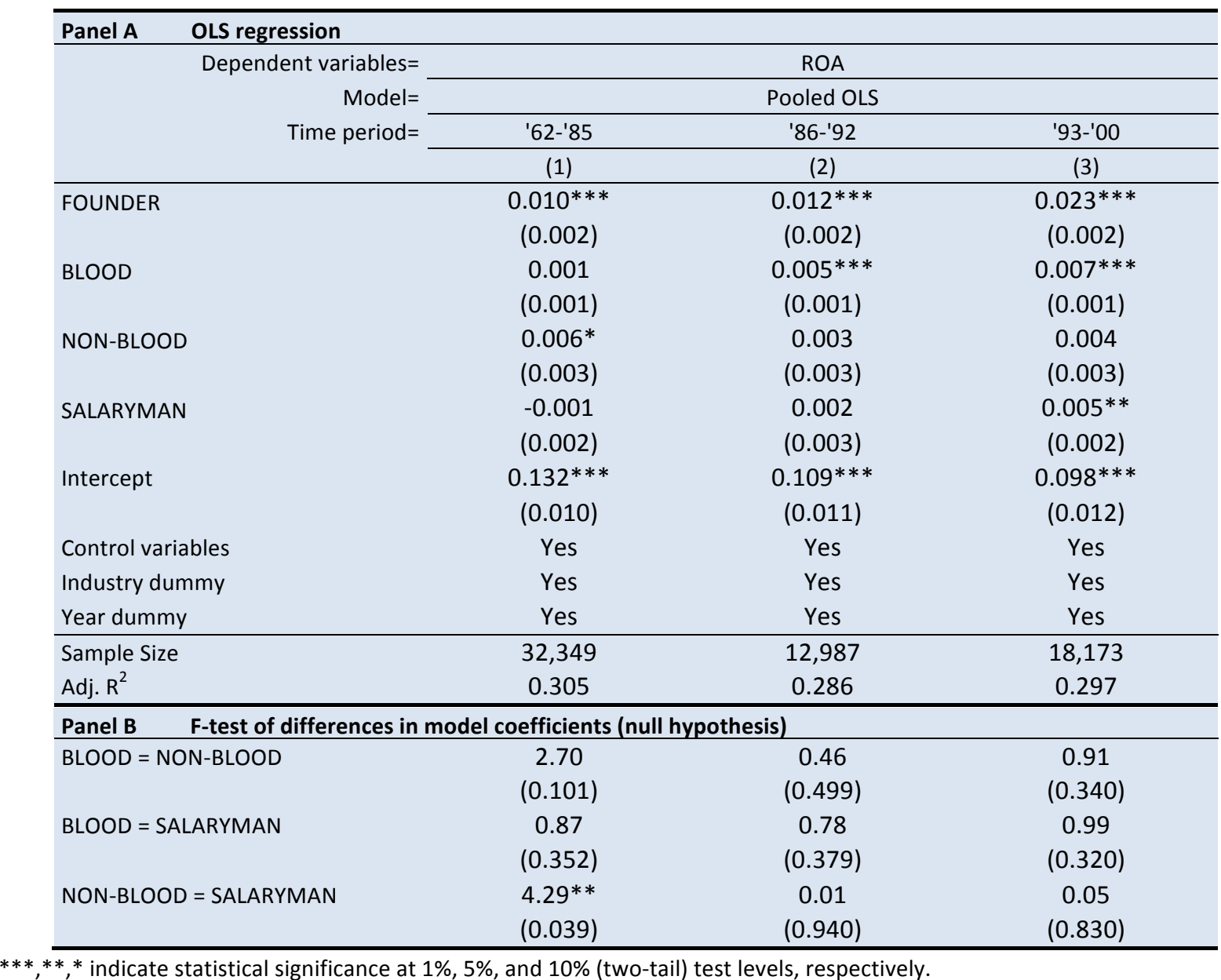

Panel A of this table shows the results of pooled OLS regressions of each time period. Control variables are $A S S E T(\log ), L E V E R A G E, A G E(\log )$. Data and all variables are the same as those defined in Tables 1 and 2. Robust standard errors (clustered by firm) are in parentheses. Panel B of this table shows the results of F-test which test the null hypothesis that the coefficients of each family firm are the same. In parentheses are $p$-values.

From this analysis, we can derive several important results. First, non-blood outperformed non-family firms and salarymen in ROA in the $1^{\text {st }}$ Era only. There is no statistically significant difference between blood and non-blood for all the three eras. Second, blood outperformed non-family firms in ROA for both the $2^{\text {nd }}$ Era and $3^{\text {rd }}$ Era. These results are consistent with our conjecture. The fact that non-blood heirs 
outperform only during the $1^{\text {st }}$ Era means that inviting good talent from outside the firm as a son-in-law was effective only when labor mobility was low and hiring non-freshmen was difficult.

Why was the performance of blood heirs so high even though the "takeover threat" does not work? This point is closely related to the corporate governance system of Japanese company community. In Japanese listed companies, only blood CEOs have a substantial equity incentive. Non-blood CEOs do not necessarily have an equity incentive because they have no right of inheritance except as they are adopted. This may be a main reason for the high performance of blood heirs compared to non-family firms. Moreover, in family firms, shareholders' monitoring has worked because of the block-holding by founders' families who have incentives and information to monitor management. Hence, even the nonheir managers (SALARYMAN) show higher ROA than non-family firms.

\section{Family firms and ROA (sub-samples of listed class)}

Next we divided the MMSW's sample firms by listed class: $1{ }^{\text {st }}$ Class listed firms of the Tokyo, Osaka, and Nagoya Stock Exchanges (hereinafter, $1^{\text {st }}$ Class); and $2^{\text {nd }}$ Class listed firms of the Tokyo, Osaka, and Nagoya Stock Exchanges, plus listed firms of local exchanges [Sapporo and Fukuoka] (hereinafter, $2^{\text {nd }}$ Class). We obtained the following results.

Table 5 Family firms and ROA (sub-samples of listed class)

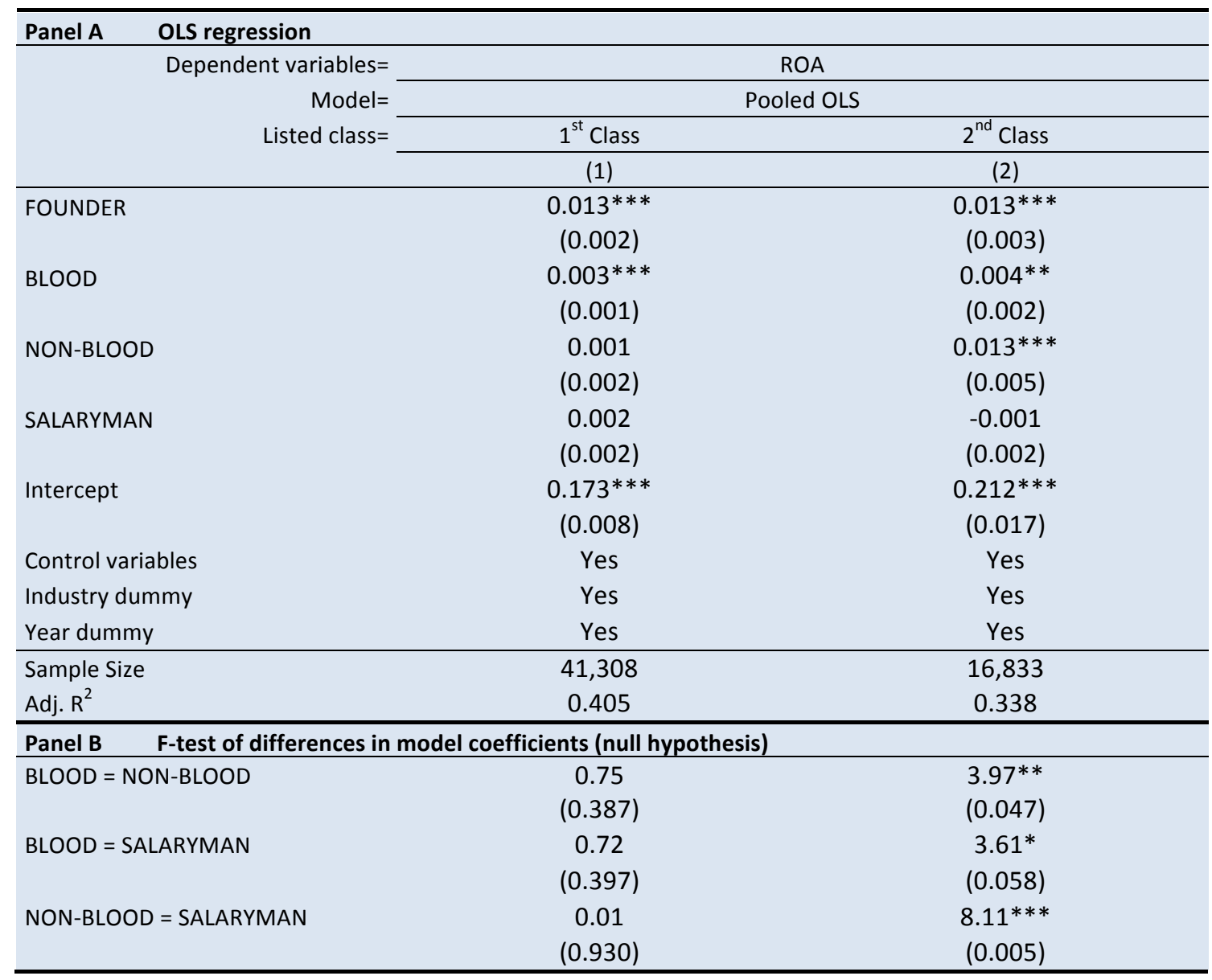

$* * *, * *, *$ indicate statistical significance at $1 \%, 5 \%$, and $10 \%$ (two-tail) test levels, respectively. 
Panel A of this table shows the results of pooled OLS regressions of each listed class. Control variables are $A S S E T(\log ), L E V E R A G E, A G E(\log )$. Data and all variables are the same as those defined in Tables 1 and 2. Robust standard errors (clustered by firm) are in parentheses. Panel B of this table shows the results of F-test which test the null hypothesis that the coefficients of each family firm are the same. In parentheses are $p$-values.

From this figure, we can see that the non-blood heirs in the $2^{\text {nd }}$ Class listed firms show significantly higher performance compared to non-family firms, blood heirs, and salarymen. This result is consistent with the hypothesis that non-blood heirs work as a substitute mechanism of labor mobility. The degree of labor mobility has generally been quite different in $1^{\text {st }}$ Class listed firms and $2^{\text {nd }}$ Class listed firms. For $2^{\text {nd }}$ Class listed firms, it is more difficult to hire good talented managers mid-career. Hence, the non-blood heirs are relatively important and show good performance in the $2^{\text {nd }}$ Class listed firms.

The performance of blood heirs is good both in $1^{\text {st }}$ Class and $2^{\text {nd }}$ Class listed firms compared to nonfamily firms. This result confirms that the equity incentive of blood heirs is important for realizing high ROA.

\section{Family firms and Tobin's q}

Next we examine Tobin's $q$ in family firms. As Table 6 shows, Tobin's $q$ of Japanese family firms is lower than that of non-family firms. Both blood heirs and non-blood heirs show negative coefficients. Even though the ROA of family firms outperforms that of non-family firms, the performance of Tobin's $q$ is not as good as ROA. This means that market tends to underestimate the performance of family firms.

Table 6 Family firms and Tobin's q

\begin{tabular}{|c|c|c|c|}
\hline \multirow[t]{4}{*}{ Panel A } & \multicolumn{3}{|l|}{ OLS regression } \\
\hline & \multirow{3}{*}{$\begin{array}{r}\text { Dependent variables= } \\
\text { Model= }\end{array}$} & \multicolumn{2}{|c|}{ Tobin's q } \\
\hline & & \multicolumn{2}{|c|}{ Pooled OLS } \\
\hline & & (1) & (2) \\
\hline \multirow[t]{2}{*}{ FOUNDER } & & $0.086 * * *$ & $0.087^{* * *}$ \\
\hline & & $(0.018)$ & $(0.018)$ \\
\hline \multirow[t]{2}{*}{ FAMILY } & & $-0.026 * *$ & \\
\hline & & $(0.012)$ & \\
\hline \multirow[t]{2}{*}{ BLOOD } & & & $-0.025^{*}$ \\
\hline & & & $(0.013)$ \\
\hline \multirow{2}{*}{\multicolumn{2}{|c|}{ NON-BLOOD }} & & $-0.049 * *$ \\
\hline & & & $(0.025)$ \\
\hline \multirow{2}{*}{\multicolumn{2}{|c|}{ SALARYMAN }} & & -0.022 \\
\hline & & & (0.017) \\
\hline \multirow{2}{*}{\multicolumn{2}{|c|}{ ASSET(log) }} & $-0.025 * * *$ & $-0.025 * * *$ \\
\hline & & $(0.005)$ & $(0.005)$ \\
\hline \multirow{2}{*}{\multicolumn{2}{|c|}{ LEVERAGE }} & $-0.359 * * *$ & $-0.359 * * *$ \\
\hline & & $(0.036)$ & $(0.036)$ \\
\hline \multirow[t]{2}{*}{ AGE(log) } & & $-0.097 * * *$ & $-0.097 * * *$ \\
\hline & & (0.019) & (0.019) \\
\hline Intercept & & $2.432 * * *$ & $2.428 * * *$ \\
\hline
\end{tabular}




\begin{tabular}{lcc} 
& $(0.120)$ & $(0.120)$ \\
Industry dummy & Yes & Yes \\
Year dummy & Yes & Yes \\
\hline Sample Size & 63,495 & 63,495 \\
Adj. ${ }^{2}$ & 0.320 & 0.320 \\
\hline Panel B F-test of differences in model coefficients (null hypothesis) & 0.92 \\
\hline BLOOD = NON-BLOOD & - & $0.337)$ \\
BLOOD = SALARYMAN & - & 0.03 \\
& - & $(0.872)$ \\
NON-BLOOD = SALARYMAN & & 0.96 \\
\end{tabular}

$* * *, * *, *$ indicate statistical significance at $1 \%, 5 \%$, and $10 \%$ (two-tail) test levels, respectively.

\section{Family firms and Tobin's q}

Panel A of this table shows the results of pooled OLS regressions. Data and all variables are the same as those defined in Table 1 and 2. Robust standard errors (clustered by firm) are in parentheses. Panel B of this table shows the results of F-test which test the null hypothesis that the coefficients of each family firm are the same. In parentheses are $p$-values.

In order to examine the reason behind the low performance of Tobin's $q$ more carefully, we have checked sub-samples of time period (Table 7) and sub-samples of listed class. From the results of Table 7, we find an interesting point: only in the $2^{\text {nd }}$ Era do family firms experience significantly lower performance of Tobin's $q$. This $2^{\text {nd }}$ Era is well-known as the "bubble period" in which the Japanese stock market experienced an asset bubbles. Asset pricing was not rational. Excessively aggressive firms were highly valued and conservative or rational firms were evaluated as too risk averse and the stock prices of those firms were underpriced. Since some family firms were conservative in this manner, the stock prices of these family firms were underpriced, and this may be one reason for the low performance of Tobin's $q$ during this era. However, Tobin's $q$ of family firms is not significantly positive even in the $1^{\text {st }}$ and $3^{\text {rd }}$ Eras. This result may be attributed to skepticism in the market about the future performance of family firms. As stressed in this paper, ROA of Japanese family firms is better than that of non-family firms since only family firms adopted the Anglo-Saxon type of corporate governance. It means, however, that if nonfamily firms adopt Anglo-Saxon type of corporate governance in the future, then the relative superiority of family firms will disappear. If financial markets expect such a possibility, the stock prices of family firms should not be high relative to ROA, and, as derived in Table 7, Tobin's $q$ should not be significantly positive. 
Table 7 Family firms and Tobin's q (sub-samples of time period)

\begin{tabular}{|c|c|c|c|}
\hline \multirow{2}{*}{$\begin{array}{l}\text { OLS regression } \\
\text { Dependent variables }=\end{array}$} & & & \\
\hline & \multicolumn{3}{|c|}{ Tobin's q } \\
\hline \multirow{3}{*}{$\begin{array}{r}\text { Model= } \\
\text { Time period }=\end{array}$} & \multicolumn{3}{|c|}{ Pooled OLS } \\
\hline & '62-'85 & '86-'92 & '93-'00 \\
\hline & (1) & (2) & (3) \\
\hline \multirow[t]{2}{*}{ FOUNDER } & $0.056 * * *$ & 0.042 & $0.152 * * *$ \\
\hline & $(0.014)$ & $(0.044)$ & $(0.045)$ \\
\hline \multirow[t]{2}{*}{ BLOOD } & -0.013 & $-0.053^{*}$ & -0.026 \\
\hline & $(0.011)$ & $(0.028)$ & (0.019) \\
\hline \multirow[t]{2}{*}{ NON-BLOOD } & -0.030 & $-0.097 * *$ & -0.034 \\
\hline & $(0.022)$ & $(0.045)$ & $(0.034)$ \\
\hline \multirow[t]{2}{*}{ SALARYMAN } & -0.013 & $-0.101 * *$ & -0.010 \\
\hline & $(0.015)$ & $(0.043)$ & $(0.030)$ \\
\hline \multirow[t]{2}{*}{ Intercept } & $1.789 * * *$ & $3.820 * * *$ & $2.892 * * *$ \\
\hline & $(0.066)$ & $(0.307)$ & $(0.206)$ \\
\hline Control variables & Yes & Yes & Yes \\
\hline Industry dummy & Yes & Yes & Yes \\
\hline Year dummy & Yes & Yes & Yes \\
\hline Sample Size & 32,333 & 12,989 & 18,173 \\
\hline Adj. $R^{2}$ & 0.267 & 0.285 & 0.193 \\
\hline \multicolumn{4}{|c|}{ F-test of differences in model coefficients (null hypothesis) } \\
\hline \multirow[t]{2}{*}{$\mathrm{BLOOD}=\mathrm{NON}-\mathrm{BLOOD}$} & 0.56 & 0.88 & 0.04 \\
\hline & $(0.454)$ & (0.349) & $(0.834)$ \\
\hline \multirow[t]{2}{*}{ BLOOD = SALARYMAN } & 0.00 & 1.10 & 0.25 \\
\hline & $(0.995)$ & $(0.294)$ & $(0.616)$ \\
\hline \multirow[t]{2}{*}{ NON-BLOOD = SALARYMAN } & 0.46 & 0.00 & 0.30 \\
\hline & $(0.496)$ & $(0.950)$ & $(0.585)$ \\
\hline
\end{tabular}

$* * *, * * *$ indicate statistical significance at $1 \%, 5 \%$, and $10 \%$ (two-tail) test levels, respectively.

\section{Family firms and Tobin's q (sub-samples of time period)}

Panel A of this table shows the results of pooled OLS regressions of each time period. Control variables are ASSET(log), LEVERAGE, AGE(log). Data and all variables are the same as those defined in Tables 1 and 2. Robust standard errors (clustered by firm) are in parentheses. Panel B of this table shows the results of F-test which test the null hypothesis that the coefficients of each family firm are the same. In parentheses are $p$-values.

Table 8 Family firms and Tobin's q (sub-samples of listed class)

\begin{tabular}{rrrr}
\hline Panel A & OLS regression & & \\
& Dependent variables $=$ & Tobin's q \\
& Model $=$ & Pooled OLS & \\
\cline { 3 - 4 } & Listed class $=$ & $2^{\text {nd }}$ Class \\
\cline { 3 - 4 } & & $(1)$ & $(2)$ \\
\hline FOUNDER & $0.102^{\text {st }}$ Class & 0.005 \\
& $(0.025)$ & $(0.025)$ \\
BLOOD & -0.020 & -0.035
\end{tabular}




\begin{tabular}{lcc} 
& $(0.016)$ & $(0.025)$ \\
NON-BLOOD & $-0.054^{*}$ & -0.051 \\
& $(0.029)$ & $(0.052)$ \\
SALARYMAN & -0.001 & $-0.043^{*}$ \\
& $(0.023)$ & $(0.026)$ \\
Intercept & $2.766^{* * *}$ & $4.539^{* * *}$ \\
& $(0.141)$ & $(0.232)$ \\
Control variables & Yes & Yes \\
Industry dummy & Yes & Yes \\
Year dummy & Yes & Yes \\
\hline Sample Size & 41,296 & 16,844 \\
Adj. R ${ }^{2}$ & 0.319 & 0.408 \\
\hline Panel B $\quad$ F-test of differences in model coefficients (null hypothesis) & 0.10 \\
\hline BLOOD = NON-BLOOD & 1.39 & $0.757)$ \\
& $(0.238)$ & 0.08 \\
BLOOD = SALARYMAN & 0.69 & $0.774)$ \\
& $(0.406)$ & 0.02 \\
NON-BLOOD = SALARYMAN & 2.57 & $(0.887)$ \\
\hline
\end{tabular}

$* * *, * *, *$ indicate statistical significance at $1 \%, 5 \%$, and $10 \%$ (two-tail) test levels, respectively.

\section{Family firms and Tobin's q (sub-samples of listed class)}

Panel A of this table shows the results of pooled OLS regressions of each listed class. Control variables are $A S S E T(\log ), L E V E R A G E, A G E(\log )$. Data and all variables are the same as those defined in Table 1 and 2. Robust standard errors (clustered by firm) are in parentheses. Panel B of this table shows the results of F-test which test the null hypothesis that the coefficients of each family firm are the same. In parentheses are $p$-values.

\section{Conclusions}

It is a wonderful puzzle why family firms (excluding founder firms) outperform non-family firms in Japan. In their recent attempt to solve the puzzle, MMSW focus on the unique Japanese custom of adopted son-in-laws. Although we admit that the adopted son-in-law practice has played an important role in Japanese family firms as a substitute for the external labor market, it has not functioned either as a threat to blood sons or as a prize to salary-men. Rather, the reason why Japanese family firms perform better in ROA than non-family firms is that, in Japan, only family firms are substantially monitored by shareholders and give CEOs a substantial equity incentive, whereas company communities pursue their private interests at the cost of shareholders in non-family firms. 


\section{References}

Anderson, R., and Reeb, D., 2003, Founding Family Ownership and Performance. Evidence from the S\&P 500. Journal of Finance 58, 1301-1327.

Bennedsen, M., Nielsen, K., Perez-Gonzalez, F., and Wolfenzon, D., 2007, Inside the Family Firm: the Role of Families in Succession Decisions and Performance, Quarterly Journal of Economics 122, 647-691.

Barth, E., Gulbrandsen, T., and Schonea, P., 2005, Family Ownership and Productivity: the Role of Owner-management, Journal of Corporate Finance 11, 107-127.

Berle, A., and Means, G., 1932, The Modern Corporation and Private Property, New York: Macmillan.

Bertland, M., and Schoar, A., 2006, The Role of Family in Family Firms, Journal of Economic Perspectives 20, 73-96.

Bertland, M., Johnson, S., Samphantharak, K., and Schoar, A., 2005, Mixing Family With Business: A Study of Thai Business Groups and the Families Behind Them, Journal of Financial Economics 88, 466-498.

Bloom, N., and Van Reenen, J., 2007, Measuring and Explaining Management Practices across Firms and Countries, Quarterly Journal of Economics 122, 1351-1408.

Burkart, M., Panunzi, F., and Shleifer, A., 2003, Family Firms. Journal of Finance 58, $2167-$ 2202.

Claessens, S., Djankov, S., and Lang, L. P. H., 2000, The Separation of Ownership and Control in East Asian Corporations, Journal of Financial Economics 58, 81-112.

Claessens, S., Djankov, S., Fan, J., and Lang, L., 2002, Disentangling the Incentives and Entrenchment Effects of Large Shareholdings, Journal of Finance 57, 2741-2471.

Cronqvist, H., and Nilsson, M., 2003, Agency Costs of Controlling Minority Shareholders, Journal of Financial and Quantitative Analysis 38, 695-719.

Davis, J., Schoorman, D., and Donaldson, L., 1997, Toward a Stewardship Theory of Management, Academy of Management Review 22, 20-47.

Dyck, A., and Zingales, L., 2004, Private Benefits of Control: An International Comparison, Journal of Finance 59, 537-600.

Faccio, M., and Lang, L., 2002, The Ultimate Ownership of Western European Corporations, Journal of Financial Economics 65, 365-395.

Jensen, M., and Mechling, W., 1976, Theory of the Firm: Managerial Behavior, Agency Costs, and Ownership Structure, Journal of Financial Economics 3, 305-360.

Leland, H., and Pyle, D., 1977, Informational Asymmetries, Financial Structure, and Financial Intermediation, Journal of Finance 32, 371-387.

Maury, B., 2006, Family Ownership and Firm Performance: Empirical Evidence from Western European Corporations, Journal of Corporate Finance 12, 321-341.

McConnaughy, D., Walker, M., Henderson, G., and Chandra, M., 1998, Founding Family Controlled Firms: Efficiency and Value, Review of Financial Economics 7, 1-19.

Mehtora, V., Morck, R., Shim, J., Wiwattanakantang, Y., 2013, Adoptive expectations: Rising sons in Japanese family firms, Journal of Financial Economics 108, 840-854.

Morck, R., Strangeland, D., and Yeung, B., 2000, Inherited Wealth, Corporate Control, and Economic Growth, in Morck, R., ed: Concentrated Corporate Ownership (University of Chicago Press, Chicago). 
Perez-Gonzalez, F., 2006, Inherited Control and Firm Performance, American Economic Review $96,1559-1588$.

Saito, T., 2008, Family firms and firm performance: Evidence from Japan, Journal of the Japanese and International Economies 22, 620-646.

Shishido, Z., 2000, Japanese Corporate Governance: The Hidden Problems of the Corporate Law and Their Solutions, Delaware Journal of Corporate Law, 25, 189.

Shleifer, A., and Vishny, R., 1997, A Survey of Corporate Governance, Journal of Finance 52, 737-783.

Smith, B., and Amoako-Adu, B., 1999, Management Succession and Financial Performance of Family Controlled Firms, Journal of Corporate Finance 5, 341-368.

Sraer, D., and Thesmar, D., 2007, Performance and Behavior of Family Firms: Evidence from the French Stock Market, Journal of the European Economic Association 5, 709-751.

Villalonga, B., and Amit, R., 2006, How Do Family Ownership, Control and Management Affect Firm Value?, Journal of Financial Economics 80, 385-417. 